\title{
Mercury Oxidation during Coal Combustion by Injection of Vanadium Pentoxide $\left(\mathrm{V}_{2} \mathrm{O}_{5}\right)$
}

\author{
Xiaofei Wang, Sijia Li, Wei-Ning Wang and Pratim Biswas* \\ Department of Energy, Environmental and Chemical Engineering \\ Washington University in St. Louis
}

St. Louis, MO 63130

\section{International Journal of Coal Geology}

February 29, 2016

Revised Version 2 Submitted

October 10, 2016

*To whom correspondence should be addressed.

Correspondence to: Pratim Biswas

Email: pbiswas@wustl.edu,

Tel: 1-314-935-5548, Fax: 1-314-935-5464 


\begin{abstract}
Although there are many commercially available methods to capture $\mathrm{Hg}$ emission from coal combustion, it is still difficult to use a single method that can control $\mathrm{Hg}$ emission both efficiently and economically from coal combustors due to the varying coal seams, operating conditions and downstream control devices. One methodology is the use of sorbent injection at elevated temperatures; and is examined in this study. $\mathrm{V}_{2} \mathrm{O}_{5}$ was tested as the sorbent and was found to effectively oxidize elemental mercury $\left(\mathrm{Hg}^{0}\right)$. Ultrafine $\mathrm{V}_{2} \mathrm{O}_{5}$ particles are formed during the combustion process resulting in a high surface area aerosol that can effectively catalyze the oxidation of $\mathrm{Hg}^{0}$. The effect of varying chlorine $(\mathrm{Cl})$ concentration in coal on $\mathrm{Hg}^{0}$ oxidation was also examined. The result shows that $\mathrm{Cl}$ can enhance $\mathrm{Hg}^{0}$ oxidation on the $\mathrm{V}_{2} \mathrm{O}_{5}$ surface.
\end{abstract}

Keywords: Mercury, sorbent, coal combustion, $\mathrm{V}_{2} \mathrm{O}_{5}$ 


\section{Introduction}

Coal combustion in the United States emits approximately 50 tons of mercury per year into the atmosphere (Houyoux and Strum, 2011). The US Environmental Protection Agency (EPA) has implemented the strict regulation of emissions of $\mathrm{Hg}$ and other pollutants from coal combustion by promulgating the Mercury and Air Toxics Standard (MATS). For example, according to the standard, if a new coal-fired power plant uses coal with the following characteristics - $\mathrm{Hg}$ content: $50 \mathrm{ppb}$, Heating value: $28 \mathrm{MJ} / \mathrm{kg}$, assumed thermal efficiency for electrical generators is $30 \%$ - then at least $91.5 \%$ of $\mathrm{Hg}$ needs to be captured. During combustion, trace amounts of mercury in coal is released in its elemental form, $\operatorname{Hg}^{0}(\mathrm{~g})$. (Pavlish et al., 2003) In the post combustion environment where the temperature is decreasing, some of $\mathrm{Hg}^{0}(\mathrm{~g})$ may be oxidized to $\mathrm{Hg}^{2+}$ compounds. $\mathrm{HCl}$ and $\mathrm{Cl}_{2}$ are important oxidants of these reactions. $\mathrm{Hg}^{2+}$ compounds can adsorb onto particulate matter in flue gas and form particulate mercury, $\operatorname{Hg}(\mathrm{p})$ (Galbreath and Zygarlicke, 2000; Senior et al., 2000a; Senior et al., 2000b). Thus, there are 3 forms of $\mathrm{Hg}$ in the exhaust gas of coal combustion: 1) $\mathrm{Hg}^{0}(\mathrm{~g})$; 2) $\mathrm{Hg}^{2+}(\mathrm{g})$; and 3) $\mathrm{Hg}(\mathrm{p}) . \mathrm{Hg}^{2+}(\mathrm{g})$ is watersoluble and can be readily removed by wet flue gas desulfurization (WFGD) systems (Zhuang et al., 2004). $\operatorname{Hg}(\mathrm{p})$ can also be easily removed by particulate matter control devices such as in baghouse fabric filters (FF) and electrostatic precipitators (ESP). However, $\mathrm{Hg}^{0}(\mathrm{~g})$ is relatively difficult to capture and it is reported that the elemental form is the main form of $\mathrm{Hg}$ emission from coal combustion systems (Pavlish et al., 2003; Presto and Granite, 2006; Wang et al., 2010).

Several technologies have been proposed to capture $\mathrm{Hg}$ in combustion exhaust. The most established method in the United States is activated carbon injection (ACI). Powdered activated carbon is injected into flue gas ductwork and absorbs $\mathrm{Hg}^{0}$. Then particulate control device can remove it with fly ash. It is a simple and efficient method. However, there are some 
disadvantages. The cost is significant (Jones et al., 2007); activated carbon (AC) will mix with fly ash and affect its flammability and salability (Pflughoeft-Hassett et al., 2009). Noticeably, there are some concrete-friendly AC sorbents that have been developed and are avaialbe on market. However, their costs are higher than traditional AC sorbents. Thus, a low cost noncarbon technology is still desired for mercury capture from coal combustion.

One general approach for a non-carbon method is promoting the oxidation of $\mathrm{Hg}^{0}$ to $\mathrm{Hg}^{2+}$, a mercury form that can be more easily captured. Many halogen species are oxidizers of $\operatorname{Hg}^{0}(\mathrm{~g})$. Chlorine is major halogen specie in coal and plays key roles in $\mathrm{Hg}$ oxidation (Senior et al., 2000b). It is reported that addition of $\mathrm{Br}_{2}$ or $\mathrm{HBr}$ can greatly enhance $\mathrm{Hg}^{0}(\mathrm{~g})$ oxidation (Liu et al. 2007; Cao et al., 2007b). Li et al. (2009) also showed that KI has the capability to oxidize $\mathrm{Hg}^{0}(\mathrm{~g})$, and demonstrated effective capture in a pilot scale study. Many metals/metal oxides can catalyze $\mathrm{Hg}^{0}(\mathrm{~g})$ oxidation, such as $\mathrm{Fe}_{2} \mathrm{O}_{3}, \mathrm{CuO}$, and some precious metals ( $\mathrm{Au}, \mathrm{Ag}$ and $\mathrm{Pd}$ ) (Galbreath et al., 2005; Ghorishi et al., 2005; Zhao et al., 2006). Besides these metals/metal oxides, selective catalytic reduction (SCR) catalysts have been studied extensively, because they have been already widely installed for NOx reduction and are also shown to have the capability of oxidation of $\mathrm{Hg}^{0}$ (Cao et al., 2007a; Cao et al., 2008; Presto and Granite, 2006). SCR catalysts are typically consist of $\mathrm{V}_{2} \mathrm{O}_{5}, \mathrm{WO}_{3}$ or zeolite supported on various carriers such as $\mathrm{TiO}_{2}$. It can help reduce $\mathrm{NOx}$ with $\mathrm{NH}_{3}$ to $\mathrm{N}_{2}$. Many studies have reported that SCR catalysts can also oxidize $\mathrm{Hg}^{0}(\mathrm{~g})$, particularly in the presence of halogen species (Cao et al., 2007a). There are several factors that can affect the performance of SCR catalysts, such as concentrations of $\mathrm{HCl}$ and sulfur oxides in flue gas (Cao et al., 2007a; Eswaran and Stenger, 2005; Senior, 2006).

Another general approach is sorbent injection into the combustion zone (high temperature sorbent) (Biswas and Wu, 1998; Biswas and Zachariah, 1997; Gale and Wendt, 2002, 2003, 
2005; Jeong et al., 2007; Lee et al., 2005; Lee et al., 2001; Suriyawong et al., 2010; Suriyawong et al., 2009; Wendt and Lee, 2010). In the high temperature combustion environment, metallic species are released to gas phase and form vapors. At the exit of combustor, when the temperature drops, these vapors will undergo homogeneous nucleation or heterogeneous condensation and form submicrometer aerosols. When sorbent particles are injected into the combustor, metallic vapors can be scavenged and these metallic species are associated with sorbent particles which usually can be designed to be in sizes that can be easily removed by the particulate matter control devices (Owens and Biswas, 1996). This methodology can be applied to $\mathrm{Hg}$ removal. For instance, $\mathrm{TiO}_{2}$ is a well-studied photocatalyst which can help oxidize $\mathrm{Hg}^{0}(\mathrm{~g})$ ( $\mathrm{Li}$ et al., 2011; $\mathrm{Li}$ et al., 2012). Wu et al. reported a method using $\mathrm{TiO}_{2}$ sorbent (Wu et al., 1998): the sorbent precursor was added into the combustor. Then the precursor was oxidized to form $\mathrm{TiO}_{2}$ agglomerate with large surface area, which can efficiently capture $\mathrm{Hg}^{0}(\mathrm{~g})$. They also showed that using UV radiation can further improve binding of $\mathrm{Hg}$ with $\mathrm{TiO}_{2}$ sorbent particles, thereby enhancing $\mathrm{Hg}$ capture and preventing its leachability when disposed to the environment. Suriyawong et al. (2009) have demonstrated the effectiveness of this method on a pilot scale. In addition, calcium- and iron-based sorbents are shown to have similar capability of $\mathrm{Hg}$ removal (Pavlish et al., 2003; Zhuang et al., 2007).

Both SCR catalysts and sorbent injection into the combustion zone (high temperature sorbent) have good performance on $\mathrm{Hg}$ capture. The combination of these two technologies may be an effective methodology for $\mathrm{Hg}$ control. $\mathrm{V}_{2} \mathrm{O}_{5}$, which is one of most active component in SCR catalysts and a relatively low-cost material, can be used as a sorbent to remove elemental Hg. This study examines the performance of this new method from pulverized coal combustion in a drop-tube furnace. Its effects on particulate matter formation have been investigated. In 
addition, the effects of chlorine and sulfur contents in coal have also been studied, since they may have significant influences on this method.

\section{Experimental Section}

The experimental setup shown in Fig. 1 consists of a coal feeding system, a drop-tube furnace (Lindberg/Blue M, Model HTF55342C, ThermoElectron Corp., USA) with an alumina reactor tube $(5.7 \mathrm{~cm}$ inner diameter, and $122 \mathrm{~cm}$ long), a cascade impactor, and various sampling and measuring systems. Pulverized Powder River Basin (PRB) sub-bituminous coal (coal particle diameter $\leqslant 50 \mu \mathrm{m}$; supplied by Ameren UE, St. Louis, MO) was introduced into the electrically heated alumina tube in the drop-tube furnace by a self-made coal feeder(design of the feeder can be found in the literature(Quann et al., 1982)) at $1.5 \mathrm{~g} / \mathrm{h}$. For all experiments, a total gas flow rate of 1.0 liter-per-minute (LPM) was fixed. At the exit of the combustor, 7 LPM particle-free air was added as primary dilution, and then a six-stage cascade impactor (Mark III, Pollution Control System Corp., Seattle, WA) was used to remove particles with diameter larger than 600 $\mathrm{nm}$ in the diluted exhaust gas. A slip stream from downstream of the impactor was then drawn to a real time scanning mobility particle sizer (SMPS, TSI Inc., Shoreview, MN) to determine the particle size distribution ranging from 9 to $425 \mathrm{~nm}$. The submicrometer particles were also collected on Teflon filters for elemental analysis by an X-ray fluorescence spectroscopy (XRF, Panalytical Epsilon 5 energy dispersive XRF spectrometer, Almelo, Netherlands), crystal determination by X-ray diffraction (XRD, Rigaku Geigerflex D-MAX/A diffractometer) and morphology examination using an FEI Nova NanoSEM 230 Scanning Electron Microscope (SEM). 


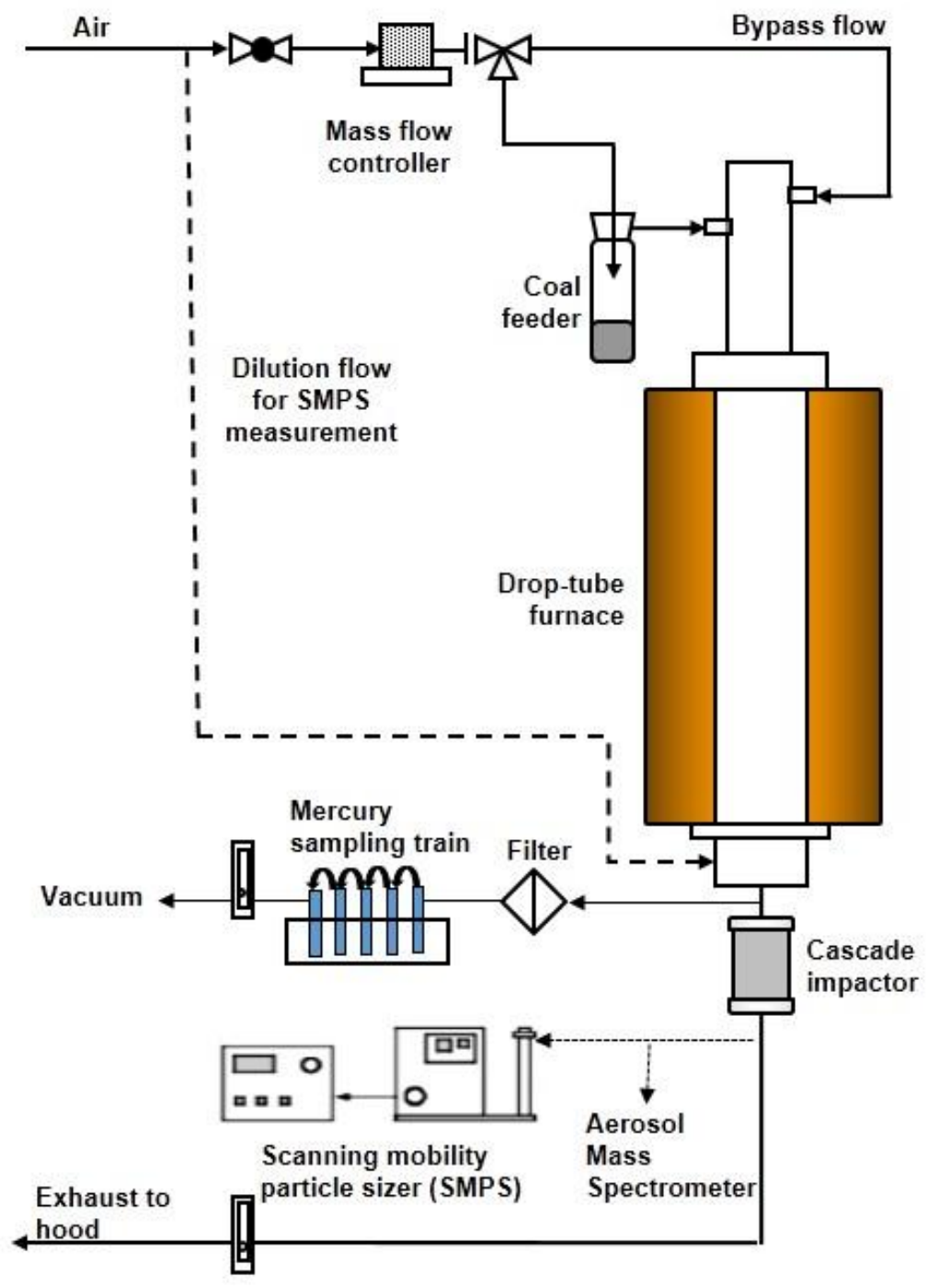

Figure 1. Schematic diagram of the experimental set-up

For mercury concentration measurements, a 0.47 LPM flue gas was drawn from the exhaust gas (before the primary dilution) and passed through a mercury sampling train to determine oxidized and elemental mercury concentrations (the dilution gas was turned off during $\mathrm{Hg}$ sampling). The sampling train and technique used for gaseous mercury collection and measurement are based on the method developed by Hedrick et al. (2001). The sampling train consists of five impingers. 
The following solutions were used to collect gaseous mercury: two impingers of $1.0 \mathrm{M}$ trisbuffer and EDTA for oxidized mercury capture, one impinger of $10 \%$ hydrogen peroxide and $2 \%$ nitric acid for oxidizing and capturing of elemental mercury, and two impingers of $0.05 \mathrm{M}$ potassium iodide and $2 \%$ hydrochloric acid for elemental mercury capture. The impinger solutions with captured mercury content were then analyzed by a direct mercury analyzer (DMA-80, Milestone S.r.l., Italy) to determine the elemental and oxidized fractions of mercury in the exhaust gas.

The overall test plan is summarized in Table 1. First, the baseline elemental mercury concentration from PRB coal combustion was determined. Set I experiments were then carried out to compare elemental mercury removal efficiency of using $\mathrm{V}_{2} \mathrm{O}_{5}$ (purity $\geq 98 \%$, particle size: 325 mesh) with $\mathrm{CuO}$ and $\mathrm{Fe}_{2} \mathrm{O}_{3}$ as sorbent at same mixing ratio (100 part-per-million based on mass, ppm). Set II experiments were designed to study the effects of varying mixing ratio of $\mathrm{V}_{2} \mathrm{O}_{5}$ on mercury removal efficiency. $\mathrm{V}_{2} \mathrm{O}_{5}$ concentrations of $50,100,300$, and 500 ppm were tested. The objects of Set III experiments were to determine the effects of chlorine content in coal on mercury capture efficiency. 
Table 1. Experimental test plan for this study

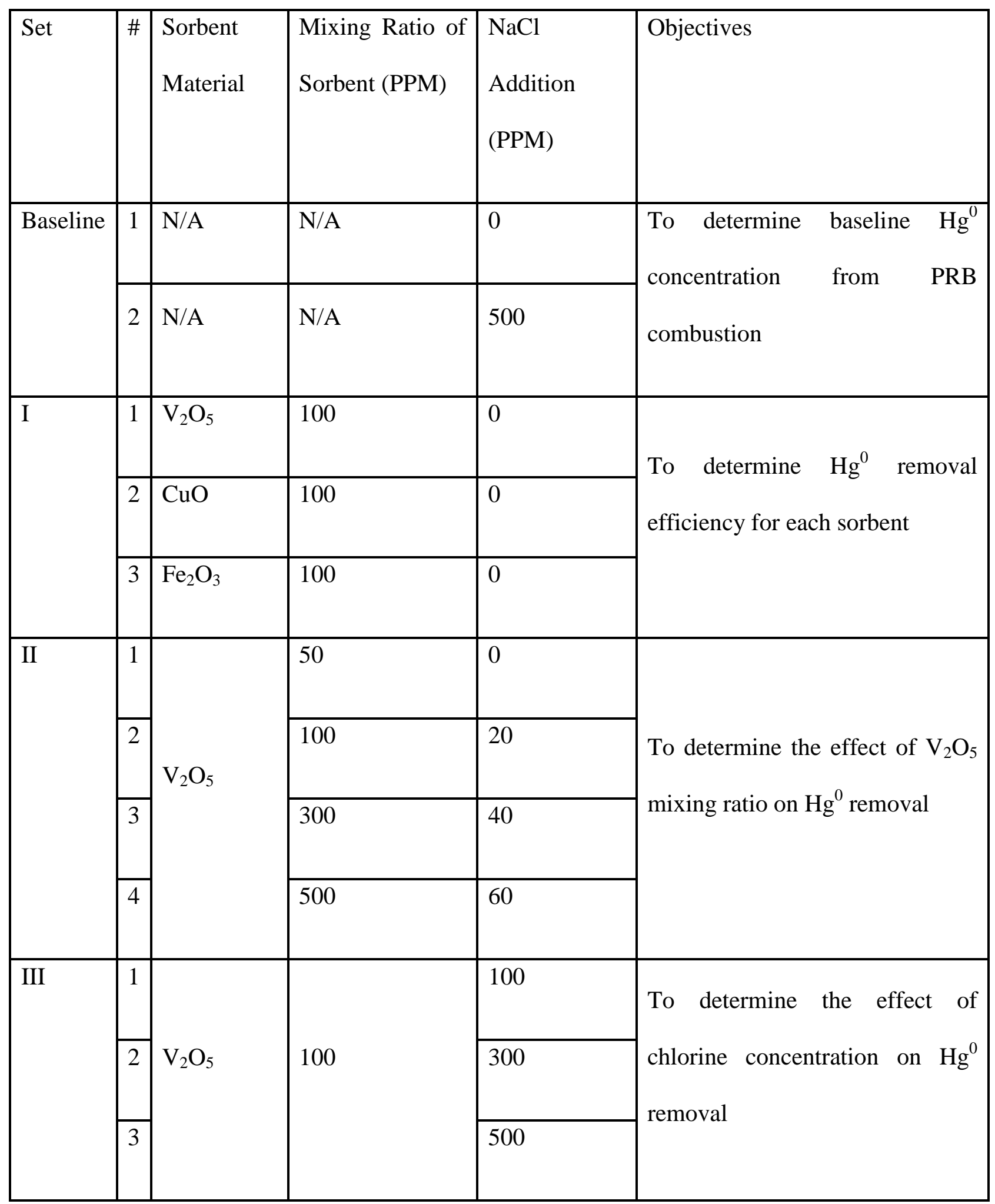




\section{Results and Discussion}

The overall study examined the performance of injecting $\mathrm{V}_{2} \mathrm{O}_{5}$ as a sorbent on elemental $\mathrm{Hg}$ oxidation from pulverized coal combustion in a drop-tube furnace at various conditions. Particulate matter formation and the effects of chlorine and sulfur contents in coal on $\mathrm{Hg}$ oxidation were also studied.

\subsection{Oxidation $\mathrm{Hg}^{0}$ by mixing $\mathrm{V}_{2} \mathrm{O}_{5}$ with coal}

As shown in Fig. 2a, $\mathrm{V}_{2} \mathrm{O}_{5}$ particles were mixed with PRB coal at different ratios (Set 1, Table 1). Without adding $\mathrm{V}_{2} \mathrm{O}_{5}$, the $\mathrm{Hg}^{0}$ concentration (the baseline concentration) in the flue gas was 2.25 $\mu \mathrm{g} / \mathrm{m}^{3}$. The $\mathrm{Hg}$ content in PRB coal was about $0.08 \mathrm{ppm}$. The coal burning rate was fixed at 1.5 gram/hour. The input air flow rate is 1 LPM. Thus, assuming all $\mathrm{Hg}$ from coal is released to the flue gas after burning, the total $\mathrm{Hg}$ concentration in flue gas should be $\sim 2 \mu \mathrm{g} / \mathrm{m}^{3}$, which was close to the measured baseline $\mathrm{Hg}$ concentration, $\sim 2.3 \mu \mathrm{g} / \mathrm{m}^{3}$. The $\mathrm{Hg}^{2+}$ concentration was only $\sim 0.05 \mu \mathrm{g} / \mathrm{m}^{3}$, which was much less than the $\mathrm{Hg}^{0}$ concentration, suggesting that there were insufficient oxidants in the combustion system, due to the low coal $\mathrm{Cl}$ concentrations in the PRB coal. When $\mathrm{V}_{2} \mathrm{O}_{5}$ was mixed with coal, the $\mathrm{Hg}^{0}$ concentration decreased significantly. For example, when the mixing ratio was $50 \mathrm{ppm}$, the $\mathrm{Hg}^{0}$ concentration was $1.09 \mu \mathrm{g} / \mathrm{m}^{3}$, and the $\mathrm{Hg}^{0}$ removal efficiency $\left(=1-\frac{\mathrm{Hg}^{0} \text { Concentration }}{\text { Baseline } \mathrm{Hg}^{0} \text { Concentration }}\right)$ was about $51.2 \%$. Experimental results show that $\mathrm{Hg}^{0}$ concentration decreased with increased $\mathrm{V}_{2} \mathrm{O}_{5}$ mixing ratio with coal, and the highest removal efficiency, $64.4 \%$, was achieved when the mixing ratio was $500 \mathrm{ppm}$. These results demonstrate that $\mathrm{V}_{2} \mathrm{O}_{5}$ is effective in the capture of $\mathrm{Hg}^{0}$. In our previous study ( $\mathrm{Li}$ et al., 2009), potassium iodine (KI) was used as a sorbent. The $\mathrm{Hg}^{0}$ removal efficiencies were $30 \%, 53 \%$ and $61 \%$, when KI mixing ratios were 235, 389 and $777 \mathrm{ppm}$, respectively, lower than the 
performance of $\mathrm{V}_{2} \mathrm{O}_{5}$. Beside $\mathrm{V}_{2} \mathrm{O}_{5}$ and $\mathrm{KI}, \mathrm{CuO}$ and $\mathrm{Fe}_{2} \mathrm{O}_{3}$ were also tested, since previous studies report that they also remove $\mathrm{Hg}^{0}$ (Galbreath et al., 2005; Granite et al., 2000; Presto and Granite, 2006). The results revealed that their $\mathrm{Hg}^{0}$ removal efficiencies were $44.4 \%$ and $28.3 \%$, respectively. Therefore, $\mathrm{V}_{2} \mathrm{O}_{5}$ has a superior performance as a sorbent.

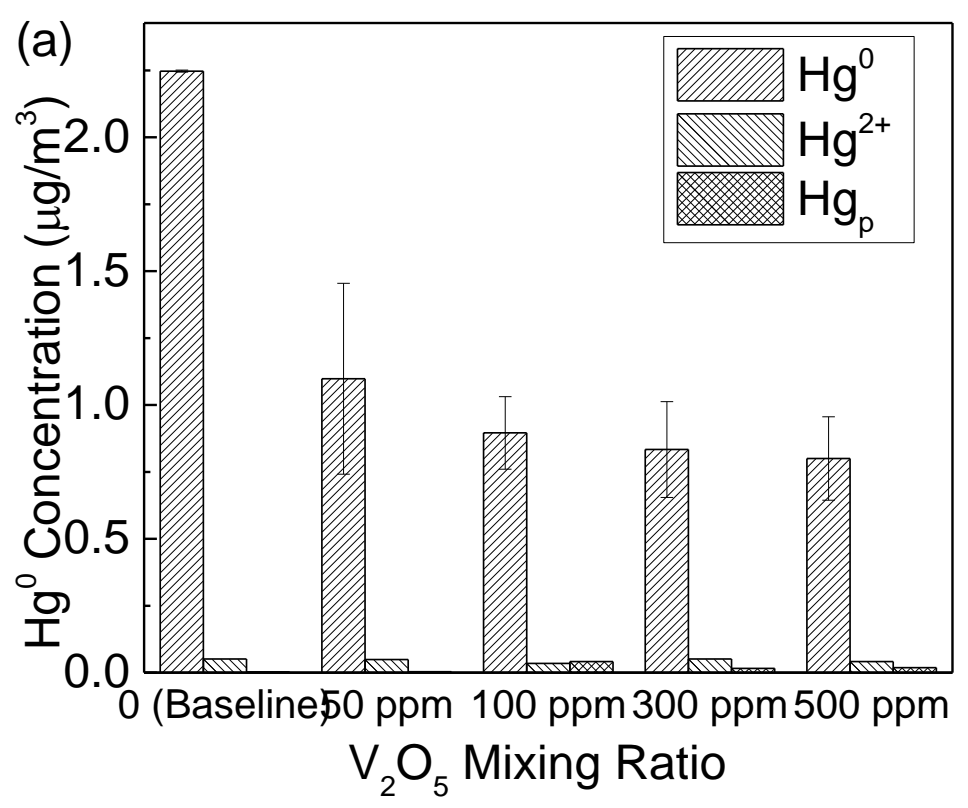



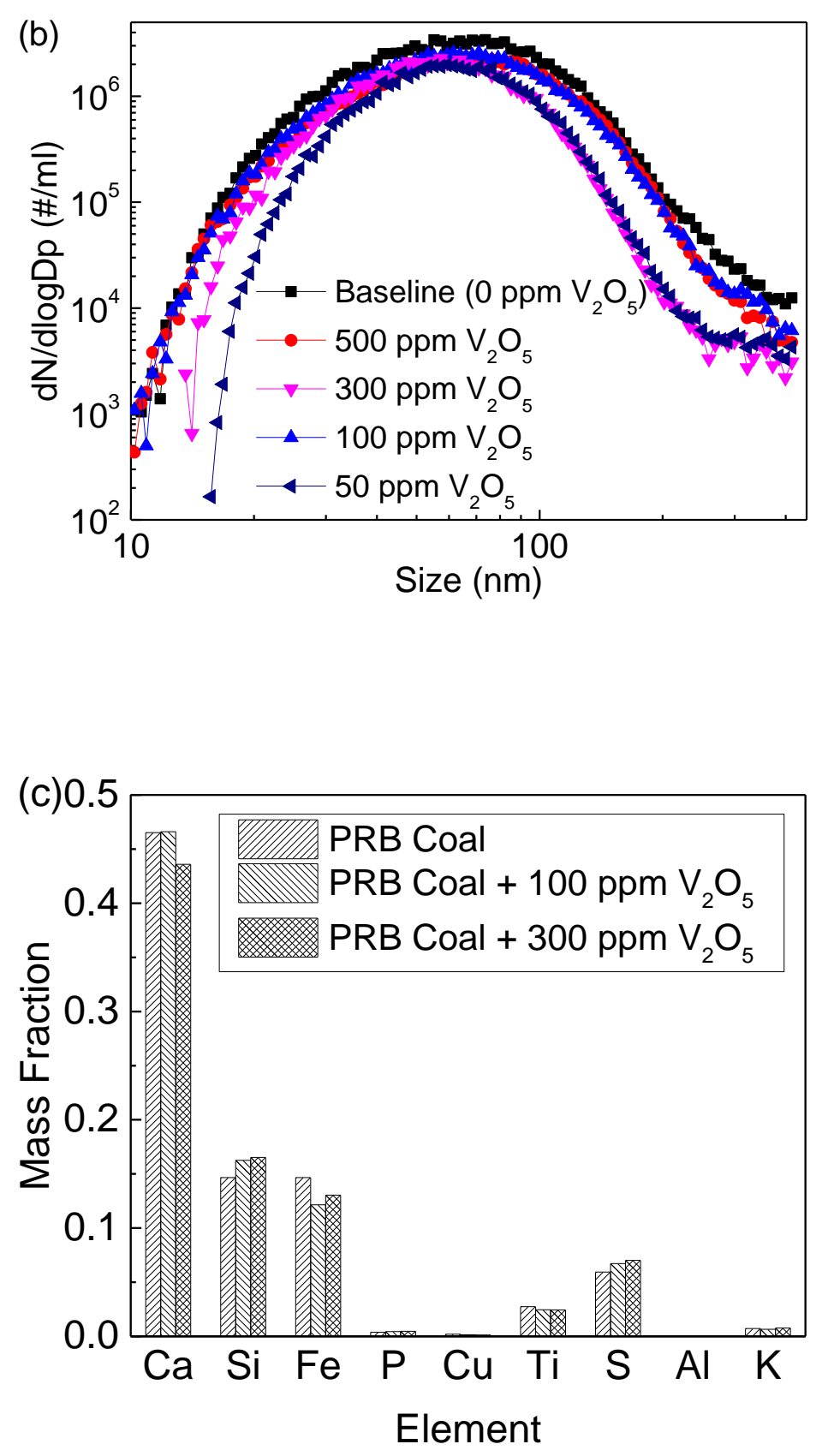

Figure 2. Combustion of $\mathrm{PRB}$ coal mixed with $\mathrm{V}_{2} \mathrm{O}_{5}$ at different ratios: (a) Mercury concentrations in the flue gas; (b) Fine particle size distribution; and (c) Elemental compositions of fine particulate matter 
Figure 2a shows that the $\mathrm{Hg}^{0}$ removal efficiency did not increase significantly on increasing the $\mathrm{V}_{2} \mathrm{O}_{5}$ mixing ratio above $100 \mathrm{ppm}$. This finding suggests that $\mathrm{V}_{2} \mathrm{O}_{5}$ was not the limiting factor in the mercury removal process. The mechanism of $\mathrm{Hg}^{0}$ oxidation by $\mathrm{V}_{2} \mathrm{O}_{5}$ is the catalytic oxidation of $\mathrm{Hg}^{0}$ on the $\mathrm{V}_{2} \mathrm{O}_{5}$ particle surface (Cao et al., 2007a; $\mathrm{Li}$ et al., 2011; Presto and Granite, 2006). $\mathrm{Hg}^{2+}$ is the product formed after this process. Thus, when $\mathrm{V}_{2} \mathrm{O}_{5}$ was added, a significant fraction of $\mathrm{Hg}^{0}$ should be converted to $\mathrm{Hg}^{2+}$ in the flue gas. However, Fig. 2a shows that $\mathrm{Hg}^{2+}$ concentrations were very low for all experiments. This can be explained by the fact that $\mathrm{Hg}^{2+}$ (such as $\mathrm{HgO}$ and $\mathrm{HgCl}_{2}$ ) has much lower vapor pressure than $\mathrm{Hg}^{0}$ (Johnson et al., 1966; Lamoreaux et al., 1987). The temperature of flue gas dropped to the room temperature very quickly in our system. This resulted in the conversion to the particulate phase or condensation of $\mathrm{Hg}^{2+}$ on existing particles or tubing surfaces. Our previous research also showed a similar result ( $\mathrm{Li}$ et al., 2009). In the bench-scale system used in this study, fine particles did not provide significant surface area $\left(\sim 1 \times 10^{-4} \mathrm{~cm}^{2} / \mathrm{cm}^{3}\right.$, calculated from particle size distribution showed in Fig. 2b), and is comparable to the surface area of the tubing. Therefore, most of $\mathrm{Hg}^{2+}$ may condense on the inside surface of the tubing, rather than on the particle surface. The low $\mathrm{Hg}$ concentrations found in particulate matter (shown in Fig. 2a) also confirms this pathway. In a full scale coal fired power plant, if $\mathrm{V}_{2} \mathrm{O}_{5}$ injection is used, an additional wet scrubber needs to be installed to remove $\mathrm{Hg}^{2+}$, because most of $\mathrm{Hg}^{2+}$ may not be adsorbed by fly ash particles and removed by particulate capture device, such as ESP and filter baghouse.

$\mathrm{V}_{2} \mathrm{O}_{5}$ addition could also impact particulate matter (fly ash) formation: adding sorbent particles could provide extra surface for condensation of metallic species during coal combustion, thereby shifting the particle size distribution to larger sizes that can be more effectively captured in devices such as the ESP (Biswas and $\mathrm{Wu}, 1998$ ). Figure $2 \mathrm{~b}$ shows the size distributions of fine 
particles from the experiment set 1 . However there is no significant difference among those size distributions, indicating that a low $\mathrm{V}_{2} \mathrm{O}_{5}$ mixing ratio does not have significant influence on fly ash particle formation. Generally, all size distributions peak at about $60 \mathrm{~nm}$. Elemental compositions for those particles are shown in Fig. 2c. Again, no significant difference was observed. Calcium $(\mathrm{Ca})$ is one of the dominant species in particulate matter, since PRB coal has high calcium content (Wang et al., 2013). Other major species include silicon (Si), iron (Fe), sulfur (S), titanium (Ti) and potassium (K). It is interesting to note that sulfur concentration in particulate matter slightly increased when more $\mathrm{V}_{2} \mathrm{O}_{5}$ was mixed with coal. The increase may be due to the oxidation of $\mathrm{SO}_{2}$ to $\mathrm{SO}_{3}$ on $\mathrm{V}_{2} \mathrm{O}_{5}$ surface, because $\mathrm{V}_{2} \mathrm{O}_{5}$ is an efficient catalyst of $\mathrm{SO}_{2}$ oxidation (Kamata et al., 2001). $\mathrm{SO}_{3}$ is a strong acidic gas. It may react with water vapor and form sulfuric acid which can easily condense on surface and enter the particle phase.

\subsection{Transformation of $\mathrm{V}_{2} \mathrm{O}_{5}$ during coal combustion}

The previous section results demonstrated that adding $\mathrm{V}_{2} \mathrm{O}_{5}$ to coal can efficiently reduce $\mathrm{Hg}^{0}$ concentration in the exhaust gas. The role that $\mathrm{V}_{2} \mathrm{O}_{5}$ plays in $\mathrm{Hg}^{0}$ removal needs to be further investigated. Pristine $\mathrm{V}_{2} \mathrm{O}_{5}$ particles were inlet into the drop-tube furnace. Particle size distribution has been measured at the outlet of the drop-tube furnace (Fig. 3a), which shows the presence of high concentration of ultrafine particles. In the SEM image (Fig. 3b) of the pure $\mathrm{V}_{2} \mathrm{O}_{5}$ particle that was collected on a Teflon filter from the outlet of the drop-tube furnace, there are some micrometer size particles and large amount of nanoparticles, which are attached to the fibers of the filter. Almost all particles have spherical shape. Figure $3 \mathrm{c}$ shows the original shape of $\mathrm{V}_{2} \mathrm{O}_{5}$ particles, most of which are rod; and their sizes are much larger $(\sim 100$ to $200 \mu \mathrm{m}$ in length). The change of size and shape strongly indicates a gas-to-particle conversion process that the $\mathrm{V}_{2} \mathrm{O}_{5}$ particles were undergoing in the furnace (Widiyastuti et al., 2009). The melting 
point of $\mathrm{V}_{2} \mathrm{O}_{5}$ is $963 \mathrm{~K}$. And the temperature inside the drop-tube furnace was around $1376 \mathrm{~K}$. Therefore, $\mathrm{V}_{2} \mathrm{O}_{5}$ particles would quickly become liquid droplet in the furnace. Some liquid may be evaporated and form $\mathrm{V}_{2} \mathrm{O}_{5}$ vapor. When the gas is leaving from the furnace and its temperature drops below $963 \mathrm{~K} . \mathrm{V}_{2} \mathrm{O}_{5}$ vapor would start nucleation process, which produce high concentration of $\mathrm{V}_{2} \mathrm{O}_{5}$ ultrafine particles. The ultrafine $\mathrm{V}_{2} \mathrm{O}_{5}$ particles provide large surface area, which can greatly facilitate the oxidation of $\mathrm{Hg}^{0}$. Fine $\mathrm{V}_{2} \mathrm{O}_{5}$ particles had been also collected for the analysis of X-ray Diffraction (XRD) (Fig. 3d). No significant peak has been found in the spectrum, suggesting that ultrafine $\mathrm{V}_{2} \mathrm{O}_{5}$ particles are in amorphous phase. Figure 4 summarizes this whole process.

(a)
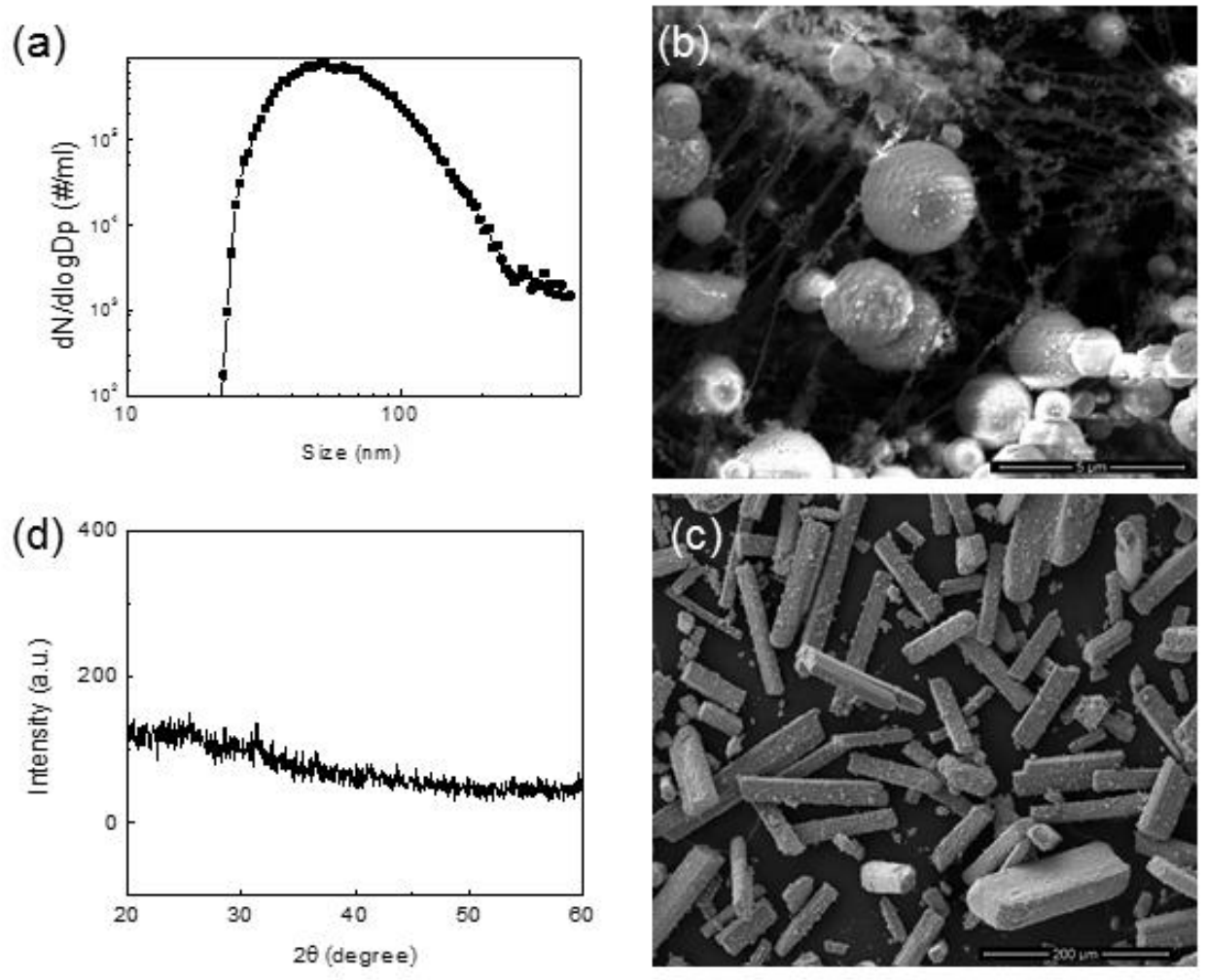

Figure 3. (a) Particle size distribution from pure $\mathrm{V}_{2} \mathrm{O}_{5}$ experiment; (b) SEM image of $\mathrm{V}_{2} \mathrm{O}_{5}$ particles collected from the outlet of the drop-tube furnace; (c) SEM image of original $\mathrm{V}_{2} \mathrm{O}_{5}$ 
particles; and (d) X-ray Diffraction (XRD) spectrum of the collected particles from pure V2O5 experiment

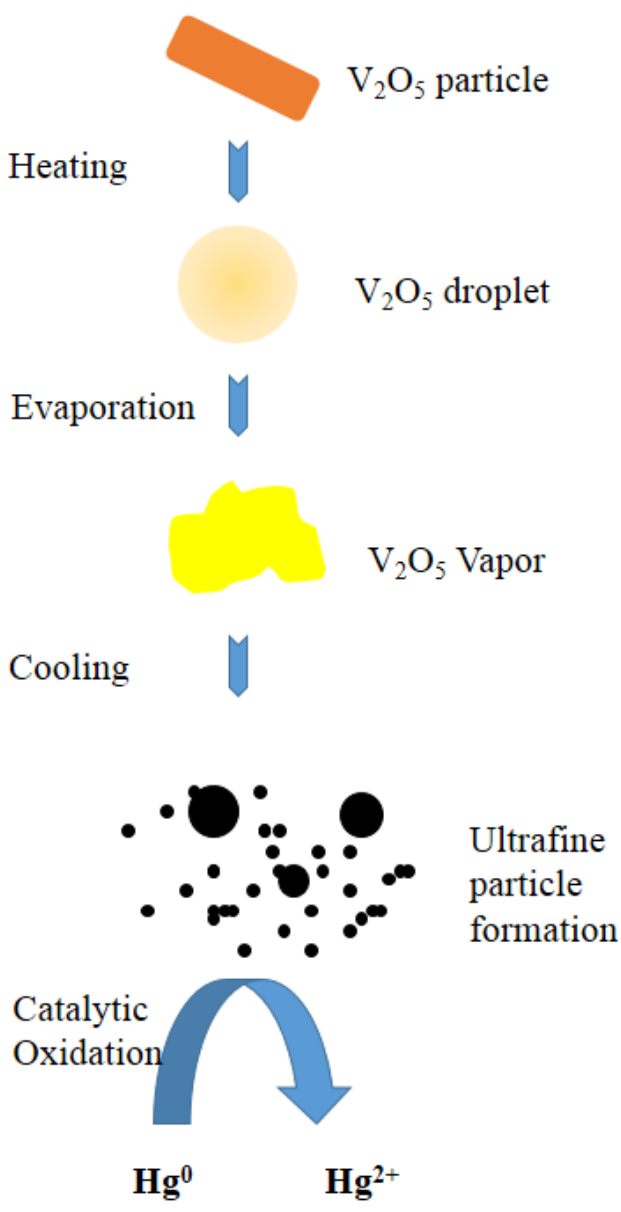

Figure 4. Illustration of ultrafine $\mathrm{V}_{2} \mathrm{O}_{5}$ particles formation

3.3 Effect of chlorine (Cl) concentration in coal on $\mathrm{Hg}^{0}$ oxidation 
During coal combustion, the trace amounts of chlorine in coal are released into the gas phase, which is the main oxidizer for $\mathrm{Hg}^{0}$ oxidation (Senior et al., 2000b; Zhuang et al., 2007). By adding different mixing ratio of $\mathrm{NaCl}$ into the mixture of $\mathrm{PRB}$ coal and 100ppm $\mathrm{V}_{2} \mathrm{O}_{5}, \mathrm{Cl}$ concentrations were changed (shown in Experiment Set 2 in Table 1); and its effect on $\mathrm{Hg}^{0}$ removal has been investigated. Figure 5a shows that $\mathrm{Hg}^{0}$ concentration decreased when $\mathrm{Cl}$ was added to coal, suggesting that $\mathrm{Cl}$ did help oxidize $\mathrm{Hg}^{0}$. This result is consistent with previous studies, which report that adding $\mathrm{Cl}$ into coal can promote the oxidations of $\mathrm{Hg}^{0}$ in both gas phase and particle surface (Galbreath et al., 2005; Zhuang et al., 2007). Moreover, Fig. 5a also shows that adding 500ppm $\mathrm{NaCl}$ and $100 \mathrm{ppm} \mathrm{V}_{2} \mathrm{O}_{5}$ has higher $\mathrm{Hg}^{0}$ oxidation efficiency than adding 500ppm $\mathrm{NaCl}$ alone (without adding $\mathrm{V}_{2} \mathrm{O}_{5}$ ), which indicates adding $\mathrm{Cl}$ probably enhanced $\mathrm{Hg}^{0}$ 's oxidation on $\mathrm{V}_{2} \mathrm{O}_{5}$ surface. Thus adding $\mathrm{Cl}$ is an effective way to enhance $\mathrm{Hg}^{0}$ oxidation. However in practice, although the halogen injection method can efficiently remove elemental $\mathrm{Hg}$ from flue gas, it could have some undesired effects, such as causing serious corrosion in power plant (Zhuang et al., 2009). Noticeably, $\mathrm{V}_{2} \mathrm{O}_{5}$ can catalyze the oxidation of $\mathrm{SO}_{2}$ to $\mathrm{SO}_{3}$, which react with water vapor to form sulfuric acid and also cause the corrosion. Thus, using the $\mathrm{V}_{2} \mathrm{O}_{5}$ injection method in power plant may have the similar undesired effect. 

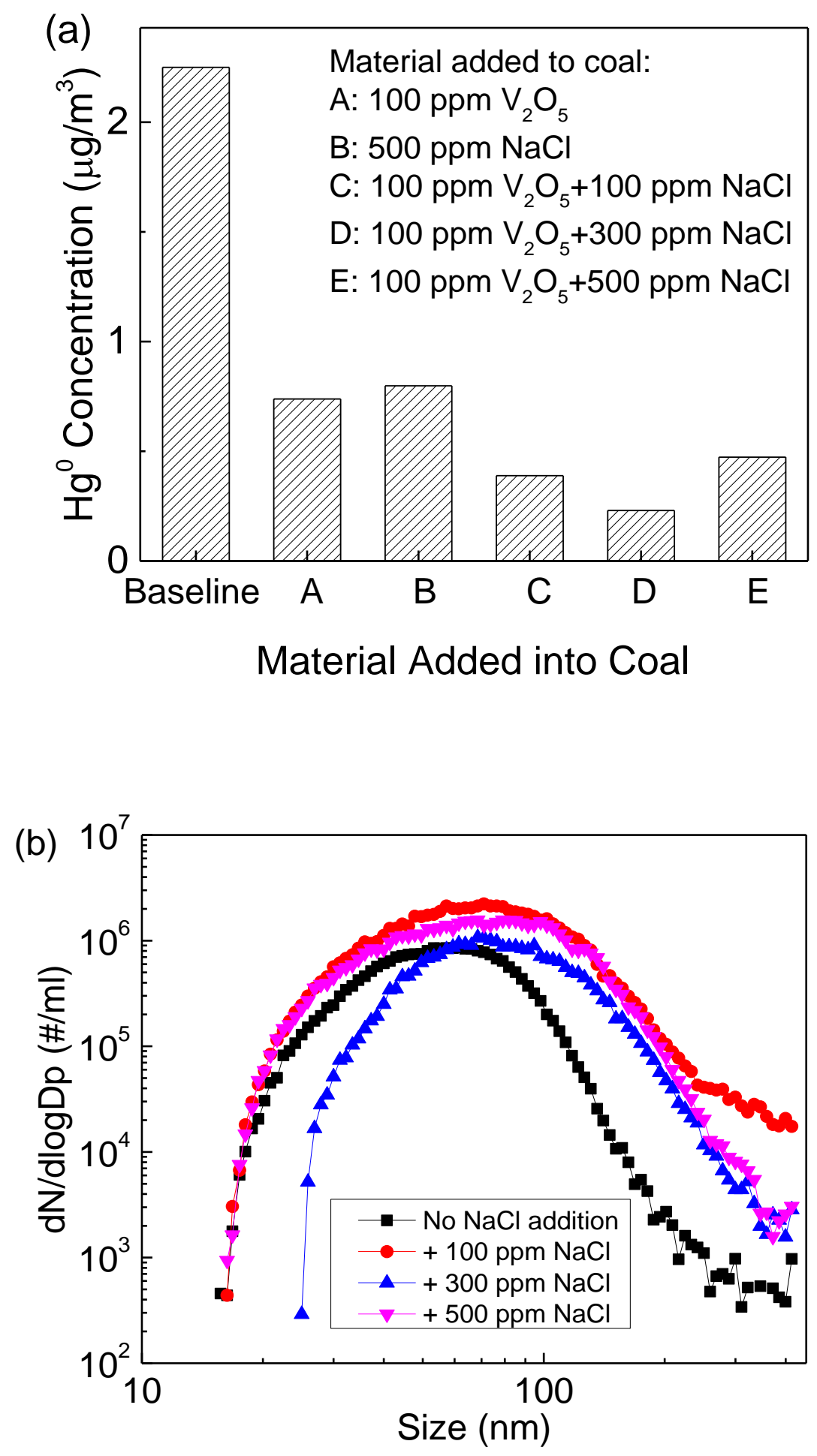


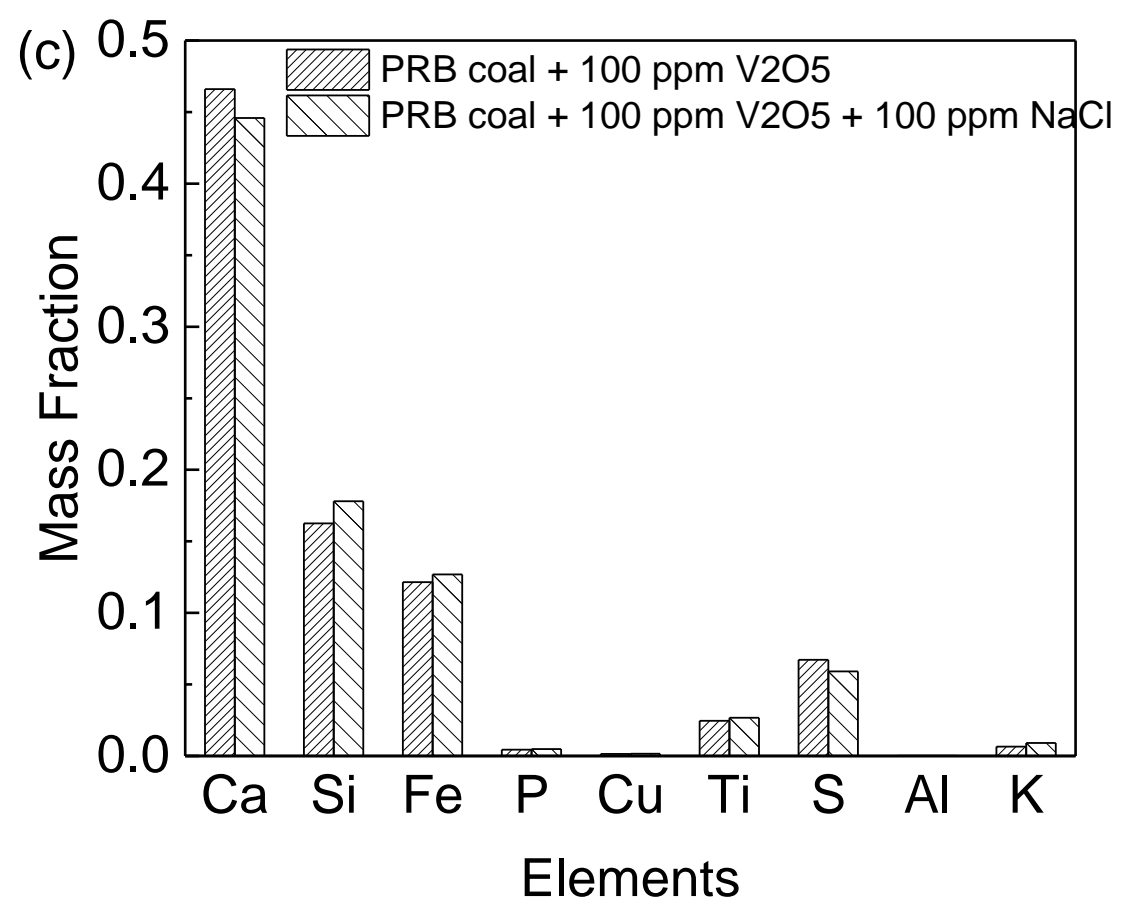

Figure 5. Effect of chlorine content in coal on mercury concentrations in the flue gas

Particulate formation was also studied. The size distribution of fine particles shifted to larger particle sizes when more $\mathrm{NaCl}$ was added (Fig. 5b). During coal combustion, $\mathrm{NaCl}$ is evaporated into gas phase readily as it is volatile at the high temperatures. At the exit of the drop-tube furnace, the temperature drops and the sodium vapor may condense on particles, thereby increasing particle sizes. This process may affect $\mathrm{Hg}$ removal by $\mathrm{V}_{2} \mathrm{O}_{5}$, since it can block some active sites on $\mathrm{V}_{2} \mathrm{O}_{5}$ particles. Thus the process may account for the decreased performance of $\mathrm{V}_{2} \mathrm{O}_{5}$ when $500 \mathrm{ppm} \mathrm{NaCl}$ was added. Elemental compositions for the fine particles are shown in Fig. 5c. No significant difference is found.

\subsection{Potential environmental impact}


It is important to notice that $\mathrm{V}_{2} \mathrm{O}_{5}$ is also a modest toxic substance to human. The lethal dose ( $\left.\mathrm{LD}_{50}\right)$ for inhalation of $\mathrm{V}_{2} \mathrm{O}_{5}$ dust is $4-11 \mathrm{mg} / \mathrm{kg}$ (Bauer et al., 2000). Efficient particulate control device is required for removal $\mathrm{V}_{2} \mathrm{O}_{5}$ particles in flue gas. The fly ash management needs to be carefully treated, because $\mathrm{V}_{2} \mathrm{O}_{5}$ could leach to groundwater. Moreover, dry fly ash particles can be easily carried away by air flow. The resuspension of fly ash during handling, transporting and reusing or landfilling processes could also introduce $\mathrm{V}_{2} \mathrm{O}_{5}$ into the ambient air and cause some health concerns.

\section{Conclusions}

This study examined the performance of injecting $\mathrm{V}_{2} \mathrm{O}_{5}$ as sorbent on $\mathrm{Hg}$ oxidation during pulverized coal combustion in a drop-tube furnace. It shows significant performance on $\mathrm{Hg}^{0}$ oxidation with about 60 to $70 \%$ of elemental mercury conversion rate at a range of 100 to 500 ppm of $\mathrm{V}_{2} \mathrm{O}_{5}$ addition. It is proposed that the injected $\mathrm{V}_{2} \mathrm{O}_{5}$ particles catalyzed $\mathrm{Hg}^{0}$ oxidation to $\mathrm{Hg}^{2+}$, and this species condenses onto fly ash and other surfaces. In full scale coal fired boiler, an additional scrubber may be required to remove $\mathrm{Hg}^{2+}$ from flue gas. On injection into the combustor, high concentrations of ultrafine $\mathrm{V}_{2} \mathrm{O}_{5}$ particles were formed. By comparing morphology of $\mathrm{V}_{2} \mathrm{O}_{5}$ particles at the inlet and outlet, the formation pathway was elucidated. The solid $\mathrm{V}_{2} \mathrm{O}_{5}$ particles are quickly converted to liquid droplets in the combustor that rapidly evaporate at the high temperatures. As the temperature drops at the exit of the combustor, $\mathrm{V}_{2} \mathrm{O}_{5}$ vapor starts nucleating to form high concentrations of ultrafine particles. These ultrafine $\mathrm{V}_{2} \mathrm{O}_{5}$ particles provide large surface areas, which can greatly facilitate the oxidation of $\mathrm{Hg}^{0}$. Particulate matter (fly ash) formation was not significantly affected by $\mathrm{V}_{2} \mathrm{O}_{5}$ injection, in terms 
of particle size distributions and chemical compositions. In addition, the experimental results show that chlorine content in coal can enhance $\mathrm{Hg}^{0}$ oxidation on $\mathrm{V}_{2} \mathrm{O}_{5}$ surface. 


\section{Acknowledgments}

This work was partially supported by a grant from National Science Foundation (NSF CBET 1437933) and the Consortium for Clean Coal Utilization at Washington University in St. Louis. Support of the McDonnell Academy Global Energy and Environment Partnership (MAGEEP) is also acknowledged. 


\section{References}

Bauer, G., Güther, V., Hess, H., Otto, A., Roidl, O., Roller, H., Sattelberger, S., 2000. Vanadium and Vanadium Compounds, Ullmann's Encyclopedia of Industrial Chemistry. Wiley-VCH Verlag GmbH \& Co. KGaA..

Biswas, P., Wu, C.Y., 1998. Control of toxic metal emissions from combustors using sorbents: A review. J. Air Waste Manage. Assoc. 48, 113-127.

Biswas, P., Zachariah, M.R., 1997. In Situ Immobilization of Lead Species in Combustion Environments by Injection of Gas Phase Silica Sorbent Precursors. Environ. Sci. Technol. 31, 2455-2463.

Cao, Y., Chen, B., Wu, J., Cui, H., Smith, J., Chen, C.K., Chu, P., Pan, W.P., 2007a. Study of mercury oxidation by a selective catalytic reduction catalyst in a pilot-scale slipstream reactor at a utility boiler burning bituminous coal. Energy Fuels 21, 145-156.

Cao, Y., Gao, Z., Zhu, J., Wang, Q., Huang, Y., Chiu, C., Parker, B., Chu, P., Pan, W.-P., 2008. Impacts of halogen additions on mercury oxidation, in a slipstream selective catalyst reduction (SCR), reactor when burning sub-bituminous coal. Environ. Sci. Technol. 42, 256-261.

Cao, Y., Wang, Q., Chen, C.-w., Chen, B., Cohron, M., Tseng, Y.-c., Chiu, C.-c., Chu, P., Pan, W.-P., 2007b. Investigation of mercury transformation by $\mathrm{HBr}$ addition in a slipstream facility with real flue gas atmospheres of bituminous coal and powder river basin. Energy Fuels 21, 2719-2730.

Eswaran, S., Stenger, H.G., 2005. Understanding mercury conversion in selective catalytic reduction (SCR) catalysts. Energy Fuels 19, 2328-2334. 
Galbreath, K.C., Zygarlicke, C.J., 2000. Mercury transformations in coal combustion flue gas. Fuel Process. Technol. 65, 289-310.

Galbreath, K.C., Zygarlicke, C.J., Tibbetts, J.E., Schulz, R.L., Dunham, G.E., 2005. Effects of NOx, alpha-Fe2O3, gamma-Fe2O3, and $\mathrm{HCl}$ on mercury transformations in a 7-kW coal combustion system. Fuel Process. Technol. 86, 429-448.

Gale, T.K., Wendt, J.O.L., 2002. High-temperature interactions between multiple-metals and kaolinite. Combust. Flame 131, 299-307.

Gale, T.K., Wendt, J.O.L., 2003. Mechanisms and models describing sodium and lead scavenging by a kaolinite aerosol at high temperatures. Aerosol Sci. Technol. 37, 865-876.

Gale, T.K., Wendt, J.O.L., 2005. In-furnace capture of cadmium and other semi-volatile metals by sorbents. Proc. Combust. Inst. 30, 2999-3007.

Ghorishi, S.B., Lee, C.W., Jozewicz, W.S., Kilgroe, J.D., 2005. Effects of fly ash transition metal content and flue gas $\mathrm{HCl} / \mathrm{SO} 2$ ratio on mercury speciation in waste combustion. Environ. Eng. Sci. 22, 221-231.

Granite, E.J., Pennline, H.W., Hargis, R.A., 2000. Novel sorbents for mercury removal from flue gas. Ind. Eng. Chem. Res. 39, 1020-1029.

Hedrick, E., Lee, T.G., Biswas, P., Zhuang, Y., 2001. The development of iodine based impinger solutions for the efficient capture of $\mathrm{Hg} 0$ using direct injection nebulization-inductively coupled plasma mass spectrometry analysis. Environ. Sci. Technol. 35, 3764-3773.

Houyoux, M.; Strum, M., 2011. Memorandum: Emissions Overview: Hazardous Air Pollutants in Support of the Final Mercury and Air Toxics Standard; EPA-454/R-11-014; Emission Inventory and Analysis Group Air Quality Assessment Division: Research Triangle Park, NC, USA. 
Jeong, S.K., Kim, S.B., Kim, S.S., Chen, X., Biswas, P., 2007. Simultaneous removal of Cd and Pb from flue gases using in-situ generated nano-sized sorbents. J. Ind. Eng. Chem. 13, 1154-1161.

Johnson, J.W., Silva, W.J., Cubicciotti, D., 1966. The vapor pressure and enthalpy of vaporization of molten mercuric chloride to the critical point. J. Phys. Chem. 70, 2985-29882988.

Jones, A.P., Hoffmann, J.W., Smith, D.N., Feeley, T.J., Murphy, J.T., 2007. DOE/NETL's phase II mercury control technology field testing program: Preliminary economic analysis of activated carbon injection. Environ. Sci. Technol. 41, 1365-1371.

Kamata, H., Ohara, H., Takahashi, K., Yukimura, A., Seo, Y., 2001. SO2 oxidation over the V2O5/TiO2 SCR catalyst. Catal. Lett. 73, 79-83.

Lamoreaux, R.H., Hildenbrand, D.L., Brewer, L., 1987. High-temperature Vaporization Behavior of Oxides. 2. Oxides of Be, Mg, Sr, Ba, B, Al, Ga, In, Tl, Si, Ge, Sn, Pb, Zn, Cd, and Hg. J. Phys. Chem. Ref. Data 16, 419-443.

Lee, M.-H., Cho, K., Shah, A.P., Biswas, P., 2005. Nanostructured Sorbents for Capture of Cadmium Species in Combustion Environments. Environ. Sci. Technol. 39, 8481-8489.

Lee, T.G., Biswas, P., Hedrick, E., 2001. Comparison of Hg0 capture efficiencies of three in situ generated sorbents. AIChE J. 47, 954-961.

Li, H., Li, Y., Wu, C.-Y., Zhang, J., 2011. Oxidation and capture of elemental mercury over SiO2-TiO2V2O5 catalysts in simulated low-rank coal combustion flue gas. Chem. Eng. J. (Lausanne) 169, 186-193.

Li, H., Wu, C.-Y., Li, Y., Zhang, J., 2012. Superior activity of MnOx-CeO2/TiO2 catalyst for catalytic oxidation of elemental mercury at low flue gas temperatures. Appl. Catal., B. 111, 381-388. 
Li, Y., Daukoru, M., Suriyawong, A., Biswas, P., 2009. Mercury Emissions Control in Coal Combustion Systems Using Potassium Iodide: Bench-Scale and Pilot-Scale Studies. Energy Fuels 23, 236-243.

Liu, S.-H., Yan, N.-Q., Liu, Z.-R., Qu, Z., Wang, P., Chang, S.-G., Miller, C., 2007. Using bromine gas to enhance mercury removal from flue gas of coal-fired power plants. Environ. Sci. Technol. 41, 1405-1412.

Owens, T.M., Biswas, P., 1996. Vapor Phase Sorbent Precursors for Toxic Metal Emissions Control from Combustors. J. Ind. Eng. Chem. Res. 35, 792-798.

Pavlish, J.H., Sondreal, E.A., Mann, M.D., Olson, E.S., Galbreath, K.C., Laudal, D.L., Benson, S.A., 2003. State review of mercury control options for coal-fired power plants. Fuel Process. Technol. 82, 89165.

Pflughoeft-Hassett, D.F., Hassett, D.J., Buckley, T.D., Heebink, L.V., Pavlish, J.H., 2009. Activated carbon for mercury control: Implications for fly ash management. Fuel Process. Technol. 90, 1430-1434.

Presto, A.A., Granite, E.J., 2006. Survey of catalysts for oxidation of mercury in flue gas. Environ. Sci. Technol. 40, 5601-5609.

Quann, R.J., Neville, M., Janghorbani, M., Mims, C.A., Sarofim, A.F., 1982. Mineral Matter and Traceelement Vaporization in a Laboratory-pulverized Coal Combustion System. Environ. Sci. Technol. 16, 776-781.

Senior, C.L., 2006. Oxidation of mercury across selective catalytic reduction catalysts in coal-fired power plants. J. Air Waste Manage. Assoc. 56, 23-31.

Senior, C.L., Helble, J.J., Sarofim, A.F., 2000a. Emissions of mercury, trace elements, and fine particles from stationary combustion sources. Fuel Process. Technol. 65, 263-288. 
Senior, C.L., Sarofim, A.F., Zeng, T.F., Helble, J.J., Mamani-Paco, R., 2000b. Gas-phase transformations of mercury in coal-fired power plants. Fuel Process. Technol. 63, 197-213.

Suriyawong, A., Chen, X., Biswas, P., 2010. Nano-Structured Sorbent Injection Strategies for Heavy Metal Capture in Combustion Exhausts. Aerosol Sci. Technol. 44, 676-691.

Suriyawong, A., Smallwood, M., Li, Y., Zhuang, Y., Biswas, P., 2009. Mercury Capture by Nanostructured Titanium Dioxide Sorbent during Coal Combustion: Lab-scale to Pilot-scale Studies. Aerosol Air Qual. Res. 9, 394-403.

Wang, S.X., Zhang, L., Li, G.H., Wu, Y., Hao, J.M., Pirrone, N., Sprovieri, F., Ancora, M.P., 2010.

Mercury emission and speciation of coal-fired power plants in China. Atmos. Chem. Phys. 10, 1183-1192.

Wang, X., Michael Daukoru, S., Torkamani, S., Wang, W.-N., Biswas, P., 2013. Role of exhaust gas recycle on submicrometer particle formation during oxy-coal combustion. Proc. Combust. Inst. 34, 34793487.

Wendt, J.O.L., Lee, S.J., 2010. High-temperature sorbents for $\mathrm{Hg}, \mathrm{Cd}, \mathrm{Pb}$, and other trace metals: Mechanisms and applications. Fuel 89, 894-903.

Widiyastuti, W., Purwanto, A., Wang, W.-N., Iskandar, F., Setyawan, H., Okuyama, K., 2009. Nanoparticle formation through solid-fed flame synthesis: Experiment and modeling. AIChE J. 55, 885895.

Wu, C.Y., Lee, T.G., Tyree, G., Arar, E., Biswas, P., 1998. Capture of mercury in combustion systems by in situ-generated titania particles with UV irradiation. Environ. Eng. Sci. 15, 137-148.

Zhao, Y.X., Mann, M.D., Pavlish, J.H., Mibeck, B.A.F., Dunham, G.E., Olson, E.S., 2006. Application of gold catalyst for mercury oxidation by chlorine. Environmental Science \& Technology 40, 1603-1608. 
Zhuang, Y., Chen, C., Timpe, R., Pavlish, J., 2009. Investigations on bromine corrosion associated with mercury control technologies in coal flue gas. Fuel 88, 1692-1697.

Zhuang, Y., Thompson, J.S., Zygarlicke, C.J., Pavlish, J.H., 2004. Development of a mercury transformation model in coal combustion flue gas. Environ. Sci. Technol. 38, 5803-5808.

Zhuang, Y., Thompson, J.S., Zygarlicke, C.J., Pavlish, J.H., 2007. Impact of calcium chloride addition on mercury transformations and control in coal flue gas. Fuel 86, 2351-2359. 


\section{Figure Captions}

Figure 1. Schematic diagram of the experimental set-up

Figure 2. Combustion of PRB coal mixed with $\mathrm{V}_{2} \mathrm{O}_{5}$ at different ratios: (a) Mercury

concentrations in the flue gas; (b) Fine particle size distribution; and (c) Elemental compositions of fine particulate matter

Figure 3. (a) Particle size distribution from pure $\mathrm{V}_{2} \mathrm{O}_{5}$ experiment; (b) SEM image of $\mathrm{V}_{2} \mathrm{O}_{5}$ particles collected from the outlet of the drop-tube furnace; and (c) SEM image of original $\mathrm{V}_{2} \mathrm{O}_{5}$ particles.

Figure 4. Illustration of ultrafine $\mathrm{V}_{2} \mathrm{O}_{5}$ particles formation

Figure 5. Effect of chlorine content in coal on mercury concentrations in the flue gas: (a) Mercury concentrations in the flue gas; (b) Fine particle size distribution; and (c) Elemental compositions of fine particulate matter 